\title{
Correction: Neglected tropical diseases and the sustainable development goals: an urgent call for action from the front line
}

Addisu A, Adriaensen W, Balew A, et al. Neglected tropical diseases and the sustainable development goals: an urgent call for action from the front line. BMJ Global Health 2019;4:e001334. doi: 10.1136/bmjgh-2018-001334

This is to inform that co-author Hailemariam Begashaw's affiliation was addressed incorrectly. His correct affiliation is: The Carter Center, Addis Abeba, Ethiopia

Below is the updated information on the authors' affiliation.

Hailemariam Begashaw ${ }^{9}$

${ }^{9}$ The Carter Center, Addis Abeba, Ethiopia.

Open access This is an open access article distributed in accordance with the Creative Commons Attribution Non Commercial (CC BY-NC 4.0) license, which permits others to distribute, remix, adapt, build upon this work non-commercially, and license their derivative works on different terms, provided the original work is properly cited, appropriate credit is given, any changes made indicated, and the use is non-commercial. See: http://creativecommons.org/licenses/by-nc/4.0/.

(C) Author(s) (or their employer(s)) 2019. Re-use permitted under CC BY-NC. No commercial re-use. See rights and permissions. Published by BMJ.

BMJ Glob Health 2019;4:e001334corr1. doi:10.1136/bmjgh-2018-001334corr1

Check for updates 